\title{
Mantar İnfeksiyonlarının Laboratuvar Tanısında Klasik Yöntemler ve Yeni Gelișmeler
}

\section{Classical Methods and New Developments in Laboratory Diagnosis of Fungal Infections}

\author{
Dolunay GÜLMEZ1(iD), Șehnaz ALP²(iD)
}

${ }^{1}$ Hacettepe Üniversitesi Tıp Fakültesi, Tıbbi Mikrobiyoloji Anabilim Dall, Ankara, Türkiye
${ }^{2}$ Hacettepe Üniversitesi Tıp Fakültesi, İnfeksiyon Hastalıkları ve Klinik Mikrobiyoloji Anabilim Dalı, Ankara, Türkiye

Makale atıfı: Gülmez D, Alp ş. Mantar infeksiyonlarııı laboratuvar tanısında klasik yöntemler ve yeni gelişmeler. FLORA 2021;26(1):34-49.

\section{ÖZ}

Mantarların etken olduğu hastalıklar dünyada çok sayıda kişiyi etkilemektedir. Son zamanlarda bağışıklık sistemini baskılayan hastalıkıarın ve tedavi uygulamalarının artması, mantar infeksiyonlarının sıkığı ve çeşitliliğinde artışa neden olmuştur. Bu durum, zamanında ve kesin tanıyı zorlaştırmış ve daha başarılı tanısal yaklaşımlara gereksinimini artırmıştır. Özellikle invaziv mantar infeksiyonlarının tanısında yeni yöntemler geliştirilerek risk altındaki hastalarda erken dönemde doğru tanının konması ve prognozun iyileştirilmesine çalışılmaktadır. Bu amaçla, tanımlanan yeni testlerin farklı hasta gruplarında ve farklı patojenler için performansları değerlendirilmektedir. Uygun bulunanlar tanı algoritmalarına eklenmektedir. Bu derlemede mantar infeksiyonlarının tanısı için kullanılan konvansiyonel ve non-konvansiyonel laboratuvar tanı testlerinin avantaj ve dezavantajları ile özetlenmesi amaçlanmıştır.

Anahtar Kelimeler: Mantarlar; Tanı; invaziv mikoz; Invaziv kandidoz; Invaziv aspergilloz

\section{ABSTRACT}

\section{Classical Methods and New Developments in Laboratory Diagnosis of Fungal Infections}

$$
\text { Dolunay GÜLMEZ', Șehnaz ALP2 }
$$

\footnotetext{
${ }^{1}$ Department of Medical Microbiology, Hacettepe University Faculty of Medicine, Ankara, Turkey

2 Department of Infectious Diseases and Clinical Microbiology, Hacettepe University Faculty of Medicine, Ankara, Turkey
}

Diseases caused by fungi affect a large number of people in the world. Recently, the increase of diseases and treatment applications that suppress the immune system has caused a rise in the frequency and variety of fungal infections. This has complicated timely and definitive diagnosis and increased the need for more successful diagnostic approaches. New methods are developed especially for the diagnosis of invasive fungal infections in order to provide early and correct diagnosis and improve prognosis in vulnerable patients. For this purpose, the performances of new tests defined are evaluated in different patient groups and for different pathogens. Those found suitable are added to diagnostic algorithms. The aim of this review was to summarize the conventional and non-conventional laboratory diagnostic tests used for fungal diagnosis with their advantages and disadvantages.

Key Words: Fungi; Diagnosis; Invasive mycoses; Invasive candidiasis; Invasive aspergillosis 


\section{GiRiş}

Dünyada var olduğu düșünülen 1-5 milyon mantar türünden birkaç yüz kadarı insanlarda infeksiyona neden olabilmekte, cok daha azı sağlıklı insanlarda etken olarak gözlenebilmektedir. Son dönemde modern tıptaki gelișmeler, mantar infeksiyonlarına açık büyük bir popülasyon yaratmıştır. Sadece insanda yerleșen patojenlerin aksine, doğada geniş rezervuarları bulunan mantarların gelecekte giderek artan sorunlar olarak karșımiza cıkması olasıdır ${ }^{[1,2]}$. Mantarlara bağlı hastalıklar, sanılandan daha fazla kișiyi etkilemektedir. Y1lda yaklașı bir milyar kișinin mantar hastalıklarından etkilendiği ve 1.5 milyon kișinin öldüğü düsünüulmektedir ${ }^{[3]}$. Mantar hastalıkları hakkındaki farkındalığı artırmayı hedefleyen uluslararası bir platform olan "Leading International Fungal Education" (LIFE, http://www.life-worldwide.org/), konuya dikkat cekebilmek amacıyla farklı ülkelerdeki mantar infeksiyonu yükünü tahmin eden modelleme calıșmalarını teșvik etmektedir. Bu amaçla 2013'ten beri yürütülen calıșmalar, dünya nüfusunun yaklașı \%80'i için ciddi mantar hastalığı riskinin varlığını ortaya çıarmıștır ${ }^{[4]}$. Türkive için yapilan calısmada, modellemenin hata potansiyeline dikkat cekilmekle birlikte, ülkemizde rastlanan mantar infeksiyonlarının belgelenenden fazla olabileceği belirtilmiștir ${ }^{[5]}$. Mantar infeksiyonlarına ilișkin farkındalı̆̆ın artması, süpheli klinik tablonun varlığında laboratuvara bildirilerek gerekli mikolojik yöntemlerin uygulanabilmesini sağlayabilecek ve olguların tanı alabilmesine yardımcı olacaktır.

Mantar infeksiyonlarının tanısı geleneksel olarak direkt mikroskopi ve kültüre dayanmaktadır. $\mathrm{Bu}$ yöntemlerin yetersiz kaldığı, gec sonuç verdiği veya uygulanamadığı durumlar sık karșımıza cıkmaktadır ${ }^{[6]}$. Yakın dönemde geliștirilen ve tanı kılavuzlarında önerilmeye bașlanan seroloji ve moleküler temelli testler, konvansiyonel testler ile birlikte kullanıldıklarında bazı hasta gruplarında tanıya katkı sağlamaktadır. İlgili merkezin hasta profili ve coğrafi yerleșimi, mantar infeksiyonlarında etkenlerin dağılımın büyük ölçüde etkilemektedir. Bu nedenle, laboratuvarda kullanılması planlanan testlerin kılavuz önerilerinin yanı sıra, merkez özelliklerine göre de planlanması gerekliliğine dikkat edilmelidir ${ }^{[6]}$. Bu derlemede, mantar infeksiyonlarının tanısında kullanılan testlerin avan- taj ve dezavantajları ile birlikte özetlenmesi amaçlanmıstır. Tanıda ve sonrasında tedavinin yönlendirilmesinde önemli rol oynayabilmesine karșın, etken mantarın tanımlanmasına yönelik yöntemler dıșarıda bırakılmıștır.

\section{Konvansiyonel Yöntemler}

Geleneksel olarak mantar infeksiyonlarının tanısı direkt mikroskopi ve kültür ile etken mantarın klinik örnekte gösterilmesine dayanmaktadır. Bu nedenle klasik tanı ve sonrasında etkenin tanımlanması mantarın morfolojisi ve yapisal detaylarından büyük ölçüde etkilenmektedir ${ }^{[7]}$. Mayalar ve küfler olmak üzere iki morfolojik mantar sekli tanımlanmıssa da, aralarındaki ayrım her zaman çok net değildir ${ }^{[6,7]}$. Maya mantarları, genellikle tomurcuklanma yoluyla aseksuiel olarak üreyen tek hücreli organizmalardır. Katı besiyerinde üremiș olan maya kolonileri genellikle düzgün kenarls ve yuvarlaktır. Maya kolonilerinin agar yüzeyindeki makroskopik görünümü bakteri kolonilerine benzediğinden, Gram boyası veya sslak preparat ile mikroskopik olarak değerlendirilmediklerinde yanlıșlıkla bakteri olarak değerlendirilebilirler. Küf mantarları, cok hücreli filamentöz mantarlardır. Küfün filamentöz doğası, kültürde üremiș olan küf kolonilerine yünsü, tüysü veya kadifemsi görünüm verir. Bazı durumlarda, aseksüel üreme yapılarının olușumu nedeniyle granüler veya tozlu miçelyum yapıları ortaya çkabilir. Ayrıca, bazı küf kolonileri düz (pürüzsüz) olabilirken, bazı maya mantarları da makroskopik olarak görülebilen filamentöz yapılar olușturabilirler. Küf kolonilerinin filamentöz aktinomiçetes kolonilerinden ayrımı gerekebilmektedir ${ }^{[7]}$. Farklı kosullarda küf veya maya formunda bulunabilen dimorfik mantarlar da tanımlanmıștır. Özellikle in vivo ortamda cok cesittli morfolojiler de gözlenebilmektedir ${ }^{[6,7]}$. Mantarlara özgü belirgin morfolojik özellikler, mantar infeksiyonlarının tanısında ve etkenin tanımlanmasında bașarı ile kullanılmıșlardır. Halen, nadir görülen etkenlerle gelisen infeksiyonların tanısında etkenin kültürde üretilerek tanımlanması gerekmektedir ${ }^{[8]}$. Ancak, kültür yapılmasının zamanında ve kesin tanımlamada yetersiz kalabildiği durumlar, diğer tanı testlerinin geliștirilmesini zorunlu kılmıștır.

Mantar infeksiyonunun tanisı amaciyla laboratuvarda uygulanacak olan tüm islemler, gerekli biyogüvenlik düzeyi kosullarına uyumlu laboratuvar- 
larda ve eğitimli personel ile gerçekleștirilmelidir. Ayrıca, kültürde gelișen mantar sporları saçlarak diğer örnekleri kontamine edebilmektedir. Moleküler yöntemlerde de, özellikle nükleik asit ekstraksiyonu așamasında infeksiyon bölgesine yakın anatomik bölgelerde veya cevrede bulunan mantarlar ile kontaminasyon olabilmektedir. Bunların önlenmesi için, mikolojik tetkiklerde ek tedbirler gerekebilmektedir ${ }^{[7]}$.

\section{Direkt Inceleme}

Direkt mikroskopide mantarlara ait yapiların saptanması, mantar infeksiyonlarının tanısında hızl1 bir yöntem olarak halen yerini korumaktadir ${ }^{[7,9]}$. İnvaziv mikozların tanısında steril vücut sıviları ve dokularda direkt mikroskopi zorunlu kabul edilmektedir ${ }^{[10,11]}$. Eğitimli ve deneyimli personel tarafından mantar yapılarının güvenilir sekilde ayırt edilebilmesi, özellikle küf üreyen kültürlerde kontaminasyon ile kolonizasyon/infeksiyon ayrımının yapılabilmesini kolaylaștırmakta ve sonucun sağlıklı bir sekilde değerlendirilmesine olanak tanımaktadir. Ancak, negatif sonuc mantar infeksiyonunu ekarte ettirememektedir. Kültür ve direkt mikroskopi sonuclarını kıyaslayan calıșmalarda duyarlılık $\% 20$ ile \%80 arasında değișmektedir ${ }^{[9]}$. Klinik örnekte bulunan mantar elemanlarının az sayıda, fragmente ve/veya nekrotik olması yanlıs negatif sonuclara neden olabilmektedir. Rutin laboratuvarda artefaktların mantar elemanlarıyla karıștırıldığı yanlıș pozitif sonuçlar raporlanabilmektedir. Bu durumlarda farklı boyama yöntemlerinin kullanı$\mathrm{m}$ ve doku reaksiyonlarının değerlendirilmesi de önem kazanmaktadır. Bunun dișında görüntünün belirli bir etken lehine veya aleyhine yanlıs yorumlandığı durumlara da rastlanmaktadır. Psödohiflerin hif olarak, antifungal maruziyeti sonrası yapısı bozulan hiflerin Mucorales takımına ait küf olarak raporlandığı durumlar olabilmektedir ${ }^{[7,9]}$. Nadiren, etkenin cins/tür duizeyinde tanımlanmasını sağlayabilecek mantar yapiları dokuda görülebilmekte ve bunlar alıșkın olmayan gözlerden kaçabilmektedir ${ }^{[12]}$. Direkt mikroskopi, tüm dezavantajlarına karșın, mantar infeksiyonlarının değerlendirilmesinde kontaminasyon, kolonizasyon ve etken ayrımının yapılmasında değerini korumaktadır ${ }^{[7,9]}$.

Klinik materyalin direkt incelemesi için çeșitli yöntemler kullanilabilmektedir.

\section{Islak Preparat}

Örneğe ait süspansiyonun lam üzerine konulup, lamelle kapatılarak kısı 1 ș1k altında incelenmesi oldukça kolay bir yöntemdir. Kuru veya akıșkan olmayan örneklerin, inceleme öncesinde serum fizyolojik gibi bir solüsyonla ișlem görmesi gerekebilir. $\mathrm{Bu}$ yöntemle maya hücreleri ve hiflerin görülmeleri mümkündür. Ayrıca; tırnak, deri kazıntısı gibi doku artığı ve hücreler içeren örneklerin potasyum hidroksit $(\mathrm{KOH})$ solüsyonu ile hazırlanması, doku materyalinin çözünmesini ve mantar yapilarının daha görünür hale gelmesini sağlayabilmektedir. Preparatların 1sıtılması, dimetil sülfoksit (DMSO) eklenmesi, boya (mürekkep, cini mürekkebi, kalkoflor beyazı, Papanicolaou gibi) eklenmesi gibi yöntemler ișlemin hızlanmas1na veya mantarlara ait yapiların belirginleșmesine katkıda bulunabilmektedir $[7,9,13]$

\section{Gram Boyama}

Mayaların coğu ve hif yapıları tamamen veya kısmen gram-pozitif boyanmaktadır. Gram ile boyanmıș preparatların mikroskopik incelemesinde boyutları ve tomurcuklanan hücre varlığı ile mayalar bakteri hücrelerinden ayırt edilebilmektedir. Gram boyama, Actinomyces ve Nocardia gibi gram-pozitif dallanan basillerin hiflerden ayrımı için de yararlı olabilmektedir ${ }^{[7,9]}$.

\section{Çini Mürekkebi ile Boyama}

Beyin omurilik sıvısı (BOS) bașta olmak üzere, sıvı klinik örnekler santrifüj edildikten sonra olușan cökelti lam üzerine alınıp, 1-2 damla cini mürekkebi ile boyanabilmektedir. Cryptococcus neoformans/gattii, nadiren de olsa diğer Cryptococcus türleri ve Rhodotorula gibi kapsülliu mayalarda kapsül, negatif boyanma ile mantar hücresi cevresinde berrak bir bosluk olarak belirginleșmekte ve gri-siyah zeminde kapsüllü, tomurcuklanan maya hücreleri gözlenebilmektedir. Bazı sușlarda in vitro ortamda gelișen kapsülün ince olması nedeniyle bu yöntemle saptanamaması da mümkündür ${ }^{[7,9]}$.

\section{Giemsa, Wright ve Papanicolaou Boyaları}

Histoplazmoz süphesi bulunan durumlarda makrofajlar içindeki maya hücrelerinin gösterilmesinde Giemsa, Wright veya Papanicolaou boyalarindan yararlanılabilmektedir ${ }^{[7,9]}$. Ancak bu boyalar mantarlara ait duvar yapısını belirginlestirmemek- 
te, doku reaksiyonunun gösterilmesine yardımcı olmaktadırlar ${ }^{[9]}$

\section{Histokimyasal Boyalar}

Biyopsi örneklerinin patolojik incelemesi, mantar infeksiyonlarının tanısı amaciyla sık kullanılmaktadır. Patoloji laboratuvarlarında sıklıkla kullanılan Hematoksilen eozin (H-E) boyası, konak reaksiyonunun gösterilmesinin yanı sıra mantarın hiyalen (renksiz) veya dematisiyöz (doğal pigmentli) olduğunun anlașılmasında yararlı olabilmektedir. Dokuda mantarları saptamak için bazı özel boyama yöntemleri de kullanılabilmektedir. Gomori'nin metenamin gümüșleme (GMS) yöntemi, arka planın minimum ölçüde boyanmasıyla yüksek düzeyde kontrast sağlayarak mantar yapılarının görülmesini mümkün kılmaktadır. Zemin boyası olarak H-E kullanilacak sekilde birleștirilerek kullanilabilen GMS, hem doku hem de mantara iliskin detaylı morfolojik inceleme sağlanabilmektedir. Periyodik asit Schiff (PAS) yöntemi ise, ic detayların gösterilmesi için kullanıșlıdır. Griedley mantar boyası, çŏ̆u mantar duvarını boyayabilmektedir. Mayer' in musikarmin boyası, mukopolisakkaritleri boyadığı için Cryptococcus neoformans gibi kapsüllü mantarlarda mukoid kapsülün gösterilmesinde kullanılabilmektedir. Melanin ve öncüllerini belirginlestiren Fontana-Masson ve diğer melanin boyaları, esmer mantarların gösterilmesi için tercih edilebilmekte$\operatorname{dir}^{[9]}$.

\section{Kalkoflor Beyazı ile Boyama}

Bir florokrom bileșik olan kalkoflor, mantarın hücre duvarındaki kitine bağlanarak uzun dalga boylu ultraviyole ısı̆ğına maruz kaldığında floresans vermekte ve floresan mikroskopta mantarı belirginleștirmektedir. Kalkoflor beyazının, potasyum hidroksit ile birlikte uygulanmasının mantara ait yapıların daha kolay görülmesini sağladığı belirtilmektedir ${ }^{[7,9]}$.

\section{Direkt İmmiinfloresan Boyama}

Belirli bir mantara karșı geliștirilen ișaretli monoklonal veya poliklonal antikorlar tanıda yardımcı olabilmektedir ${ }^{[9]}$. Pneumocystis jirovecii tanısında floresan ișaretli spesifik antikorlar ile boyama tercih edilmektedir ${ }^{[7,9,14]}$. Blastomyces, Cryptococcus, Histoplasma, Coccidioides, Pneumocystis, Sporothrix, Paracoccidioides, Penicillium, Candida, Aspergillus, ve Mucorales gibi cok farklı man- tarların tanısı için geliștirilmiș testler bulunsa da çapraz reaksiyonların sorun olabileceği bildirilmiștir ve rutin laboratuvarlarda yaygın olarak kullanılmamaktadır ${ }^{[9]}$.

\section{Kültür Yöntemi}

Kültür yönteminin en önemli avantajı, saf olarak elde edilen patojenin kesin olarak tanımlanmasına ve gerekli durumlarda antimikrobiyal duyarlllık testlerinin yaplabilmesine olanak sağlamasıdır. Tüm mikrobiyolojik kültürlerde olduğu gibi, mantar kültürünün bașarısı için de infeksiyon bölgesinden yeterli miktarda örnek alımı gereklidir. Kültür için infeksiyon bölgesinden alınan doku ve sıvı örnekleri tercih edilmektedir. Zorunlu olmadikça sürüntü örneklerinden kaçınılmalıdır. Daha invaziv yöntemlerle alınan örnekler, örneğin balgama kiyasla bronkoalveolar lavaj (BAL), etken mantarın üreme olasılığını artırabilmektedir. Ancak, invaziv örnek almanın zorlukları ve olası komplikasyon riski nedeni ile bu karar her hastanın durumuna göre alınmalıdır ${ }^{[7,15,16]}$. Özel besiyeri veya inkübasyon koșulları gerektiren mantarların (Örneğin Malassezia veya Histoplasma türleri gibi) etken olduğu düsünülüyorsa laboratuvara bildirilmesi uygun olacaktır $^{[7,16]}$. Mantar infeksiyonlarının tanısında kültür yöntemlerinin duyarllığı sınırlıdır. Örneğin, kan kültürlerinin dissemine kandidoz olgularının yaklașık \%50 kadarını tespit edebildiği düșünülmektedir $^{[17]}$. Kan kültürü, kandidemi olmadan gelișen derin yerleșimli kandidozlarda ise yararlı olamamaktadır [15]. Fusarium veya Scedosporium'un etken olduğu hyalohifomikozlarda kan kültürlerinin yaklașı yarısında üreme gözlenebilmektedir ${ }^{[8]}$. Aspergilloz için BAL kültürlerinin duyarlllığının \%30-60 arasında değiștiği bildirilmiștir ${ }^{[16]}$. Kültür duyarllığını artırmak için $2 \mathrm{~mL}$ 'nin üzerindeki hacimlerde gönderilen steril vücut sıviları ve BAL örneklerinin santrifüj edilerek dipteki tortudan ekim yapılması önerilmektedir ${ }^{[7,18]}$. Homojen olmayan örnekler de sorunludur. Solunum yolu örneklerinden standart ekim yapilabilmesi amaciyla homojenizasyon ve dilüsyon yapıldığında kültürün duyarlılığı azalmaktadır. Seyreltilmeyen örneklerden yapilan ekimler, yüksek hacimde örneğin kültürüne olanak tanıyarak aspergilloz tanısında duyarllı̆̆ı artırabilmektedir ${ }^{[19]}$. Doku örnekleri de mikroorganizma içeriği açısından homojen değildirler. Bu nedenle alınan dokunun en az bezelye 
boyutunda olması ve hiflerin (özellikle Mucorales takımına ait küf mantarlarına ait septasız hiflerin) hasar görmemesi için ezilmeden kesilip küçük parçalara ayrılarak ekilmesi önerilmektedir ${ }^{[7,18]}$. Ayrıca, kültürde etken mantarların üremesi zaman alıcıdır $^{[7,18]}$. Bazı yavaș üreyen mantarların (dermatofitler, Histoplasma, Blastomyces gibi) ortaya çkması iki haftayı așabilmektedir ${ }^{[7]}$. Buna ek olarak, özellikle filamentöz mantarlarda tipik morfoloji gösteren olgun kolonilerin gelișmesi de zaman almaktadır. Uzun süreli inkübasyon, kültür plaklarında kuruma ve kontaminasyon riskini de beraberinde getirmektedir. Kültürde üretilemeyen mantarlar da bulunmaktadır. Atipik bir mantar cinsi olan Pneumocystis, rutin laboratuvarda kullanılan yöntemler ile kültürde üretilememiștir ${ }^{[20]}$. Belirtilen dezavantajlarına karșın, kültür yöntemleri mantar infeksiyonlarının tanısında zorunlu ve altın standart tanı yöntemi olarak yerini korumaktadır $[10,11]$.

Mantarların kültürde üretilebilmeleri amacıyla örnekler genel amaçı mantar besiyerlerine ekilirler. En sık kullanilan besiyeri pH's1 5,5-5,6 olan Sabouraud dekstroz agardir (SDA). Patates dekstroz agar, SDA'nın daha az glukoz içeren ve $\mathrm{pH}$ 's 1 6,8-7,0 olan Emmons modifikasyonu ve "inhibitory mold agar" da klinik mikoloji laboratuvarlarında genel izolasyon besiyeri olarak kullanilabilmektedir ${ }^{[7]}$. Steril olmayan bölgelerden veya kontamine olma olasılığı bulunan bölgelerden alınan örneklerin ek olarak seçici bir besiyerine de ekilmesi önerilir. Örneğin; dermatofitler için mikobiyotik agar, "inhibitory mold agar" gibi antibiyotik ve saprofit mantarları inhibe eden sikloheksimid içeren besiyerleri kullanılabilmektedir. Doku örnekleri için, özellikle dimorfik bir mantarın etyolojik ajan olabileceği durumlarda, antibiyotik eklenmiş kanlı beyin kalp infüzyon agar gibi zenginleștirilmiş besiyerleri önerilmektedir. Malassezia türleri gibi üremesi için ek besin gereksinimi olan mantarlar için Leeming-Notman veya Dixon besiyerleri uygun olabilmektedir ${ }^{[7,13]}$.

Klinik örneklerden maya mantarlarının üretilebilmesi için kromojenik besiyerleri de kullanıma girmiștir. Bu besiyerlerinde; sı k rastlanan Candida albicans, Candida tropicalis, Candida glabrata ve Candida krusei gibi türler farklı renklerde koloniler olușturmaktadırlar. Bu besiyerinin, bir örnek içinde farklı Candida türlerinin karıșk kültürlerini saptamada elverișli olduğu gösterilmiștir ${ }^{[7,21]}$.
Mantarların büyük bir bölümü 1-2 haftada in vitro olarak üreyebilmektedir. Dermatofitler ve termal dimorfik mantarlar gibi daha yavas üreyen mantarlar için, iki haftadan daha uzun süre beklemek gerekebilmektedir. Özellikle yüzeyel infeksiyon etkeni mantarların üremesini desteklemek amacıyla $36 \pm 1^{\circ} \mathrm{C}^{\prime}$ ye ek olarak daha düșük sıcaklıklarda $\left(30^{\circ} \mathrm{C}\right.$ hatta $25^{\circ} \mathrm{C}$ 'de) inkübasyon önerilmektedir ${ }^{[7]}$.

Kan kültürlerinden mantarların izolasyonu için, otomatik kan kültürü sistemleri tercih edilmektedir. $\mathrm{Bu}$ sistemlerde genellikle 5-7 gün inkübasyon sonrasında çoğu mantar izole edilebilmekteyse de, inkübasyonun 10 güne kadar uzatılmasının $C$. glabrata ve $C$. neoformans gibi patojenlerin üreme oranlarını artırdığı belirtilmiștir ${ }^{[7]}$. İnkübasyon süresi; küf mantarlarından süphelenildiğinde 14 güne, Histoplasma capsulatum veya Blastomyces dermatitidis suiphesinde 6-8 haftaya kadar uzat1labilmektedir ${ }^{[18]}$. Mantarlar aerobik organizmalar olduklarından saptanmaları için aerobik kültür siseleri tercih edilmekte, anaerobik șiselerde üreme oranları azalmaktadır ${ }^{[22]}$. Ticari sistemlerde hangi mantarların üremesinin desteklendiŏini kontrol etmek için üreticinin kılavuzları kontrol edilmelidir ${ }^{[18]}$. Bazı sistemlerde özel mikolojik șișelerin kullanımı önerilmektedir $^{[7,23]}$. Örneğin, BACTEC sisteminde (BD diagnostics, ABD) mantara özgü șișelerin kullanımı ile C. glabrata izolasyonu artmakta ve daha erken pozitif sinyal alınabilmektedir ${ }^{[24]}$. Farklı ticari sistemlerin performanslarinda da farklılıklar bulunmaktadır. Sık görülen bes Candida türünü standart miktarlarda aerobik, anaerobik ve mikolojik sișelere ekleyerek BACTEC ve BacT/Alert (BioMйrieux, Fransa) sistemlerini karșılaștıran bir çalıșmada, mikolojik șișe kullanıldığında pozitif sinyalin daha erken alınabildiğini gösterilmiștir. Ancak; aerobik sișeler kullanıldığında BacT/Alert sisteminde tüm pozitif sișeler saptanırken, BACTEC sisteminde yalancı negatiflikler gözlenmiștir ${ }^{[22]}$. H. capsulatum ve küflerin kandan izolasyonunda lizis-santrifüj sistemlerinin avantajlı olduğu da bildirilmiștir ${ }^{[7]}$. Kan kültüründe mantar üremesinden süphelenildiği durumlarda, etken mantara ve kullanilan yönteme göre gerektiğinde mikolojik sișelerin kullanımı tanıya katkı sağlayabilmektedir.

Steril olmayan örneklerde gözlenen mantar üremelerinin hastalık etkeni olup olmadıklarının anlașılması, mantarların mikrobiyota üyesi olarak vücudun farklı bölgelerinde bulunabilmeleri nedeniyle güc 
olabilmektedir ${ }^{[15]}$. Örneğin, idrar örneklerinde bakteriyel üremelerin klinik anlamını ortaya koyabilmek için kantitatif ekim yapilmakta ve üreyen bakterinin koloni sayısı ile birlikte değerlendirme yapılmaktadır. Oysa, mantar üremelerinde koloni sayılarının hastalık durumu ile ilișkisi gösterilememiștir [25]

Kültuirde elde edilen patojenin tanımlanması da önemli bir süreçtir ve etken mantarlarda zaman alıcıdır. Tanımlamanın hızlandırılması için matriks aracilı lazer desorpsiyon iyonizasyon-uçus süresi kütle spektrofotometrisi (MALDI-TOF MS) kütüphanelerinin genișletilmesi cabaları son dönemde büyük bașarı göstermiștir ${ }^{[7]}$. Ayrıca özellikle kan kültuirlerindeki üreme sonrasında katı besiyerinde subkültür yapılmadan etkenin tanımlanmasına yardımcı olan yöntemler de geliștirilmektedir. Bu yöntemler, maya üreyen kan kültürü sișelerinde uygulanmakta ve doğrudan siședen germ tüp testi gibi daha geleneksel yöntemlerden ${ }^{[26]}$, sik rastlanan kandidemi etkenlerini tanıyan floresan ișaretli molekuiler problar kullanan PNA-FISH ${ }^{[7,15,18,27]}$ veya șiseden doğrudan MALDITOF-MS ile tanımlama yapan SepsiTyper (Bruker Dantoniks, Almanya) ${ }^{[28]}$ gibi sistemlere kadar değișmektedir.

\section{Non-konvansiyonel Testler}

Mantar infeksiyonlarının tanısında direkt mikroskopi ve kültürün yetersiz kalması, farklı tanı testlerine ihtiyaç doğurmuștur. Sık gözlenen Candida veya Aspergillus gibi etkenlerin tespit edilmesine yönelik testler kullanıma girmiștir. Etken olabilecek tüm mantarların kapsamaya çalısan "panfungal" testler de bulunmakta ve geliștirilmeye çalıșlmaktadır. Böylece, nadir görülen etkenlerin de tanıda atlanmaması hedeflenmektedir ${ }^{[6,7,15]}$. Bu bölümde sözü geçen non-konvansiyonel testlerin, tek bașlarına değil geleneksel yöntemler ile birlikte kullanımı önerilmektedir. Çoğu durumda birden fazla non-konvansiyonel testin kullanımı tanıya ve farklı klinik tabloların ayrımına katkı sağlamaktadir ${ }^{[11,29,30]}$. Sik gözlenen fırsatçı infeksiyonlarda konvansiyonel testlere ek olarak kullanilabilen testler Tablo 1'de özetlenmiștir.

\section{Antijen ve Antikor Temelli Tanı Testleri}

Bazı patojen mantarlar için antijen ve antikor saptanması temeline dayalı testler bulunmaktadır. İmmünkompromize hastaların yeterli hümoral yanıt olușturamaması, antikor saptama testlerinin bu grup hastalarda kullanılabilirliğini kısıtlamaktadir $[11,15,16,29]$.

\section{1,3-beta-D-glukan}

Mantarların çoğunda duvar yapısının önemli bir bileșeni olan 1,3-beta-D-glukanın serumda tespiti, "panfungal" bir test olarak invaziv mikozların tanısına yardımcı olabilmektedir. Glukanların, invaziv mantar infeksiyonlarında etken mantarın hücre duvarından sistemik dolașıma salındığı gösterilmiștir. 1,3-beta-D-glukan testi etken mantarı ayırt edememekle birlikte, riskli hasta gruplarında invaziv mikoz tanısında yüksek duyarlılık ve özgüllüğe sahiptir. Konak faktörleri ve diğer tanısal testlerle birlikte değerlendirildiğinde, yüksek negatif prediktif değeri sayesinde invaziv mikoz tanısının ekarte edilmesinde yararlı olmaktadir ${ }^{[16]}$. Ancak, immünkompetan cocuklarda ortalama 1,3-beta-D-glukan düzeylerinin yüksek olması ve cocuklar icin optimal eșik değerlerinin belirlenmemiș olması nedeniyle pediatrik hastalarda değerlendirilmesi sorunludur. Cocuklarda invaziv aspergilloz tarama ve tanısında 1,3-beta-D-glukan testinin kullanilmaması önerilmektedir ${ }^{[31]}$. Ayrica; testin Mucorales tak1mi, Cryptococcus ve Blastomyces gibi önemli bazı patojenlerin neden oldukları infeksiyonlarda yararlı olamayacağı akılda tutulmalıdır ${ }^{[17,32]}$. Hastada mantar kolonizasyonu, eszamanlı bakteriyemi (özellikle Streptococcus türleri ile) veya mukozit varlığında, selüloz membranlar kullanılarak hemodiyaliz uygulanan hastalarda, beta-glukan içeren selüloz filtrelerle ișlem görmüș immünoglobülin, albümin ve diğer kan ürünlerini alanlarda, gazlı bez ve bazı ilaçların kullanımı durumunda da yalancı pozitiflik gözlenebilmektedir ${ }^{[10,17,32]}$. Ilk Food ad Drug Administration (FDA) ve CE onaylı (Avrupa Ekonomik Bölgesi'nde satıs için gerekli yasal gerekliliklere sahip olduğunu gösteren belge, https:// ec.europa.eu/growth/single-market/ce-marking/) ticari 1,3-beta-D-glukan testleri hasta serumu ile Limulus amebosit lizatı (LAL) arasındaki reaksiyonu kolorimetrik olarak ölçmektedir ${ }^{[17,33,34]}$. Bu yöntemin maliyet etkin olabilmesi için rutin laboratuvarlarda hasta örneklerinin biriktirilerek belirli günlerde calıșılması gerekmekte, test sonuçlarında varyasyon oranının yüksek olması nedeniyle örneklerin cift calıșılması önerilmekte ve okumanın kolorimetrik olması (sarı renk değișimi) nedeniyle hemolizli veya lipemik serum örneklerinde yalancı 


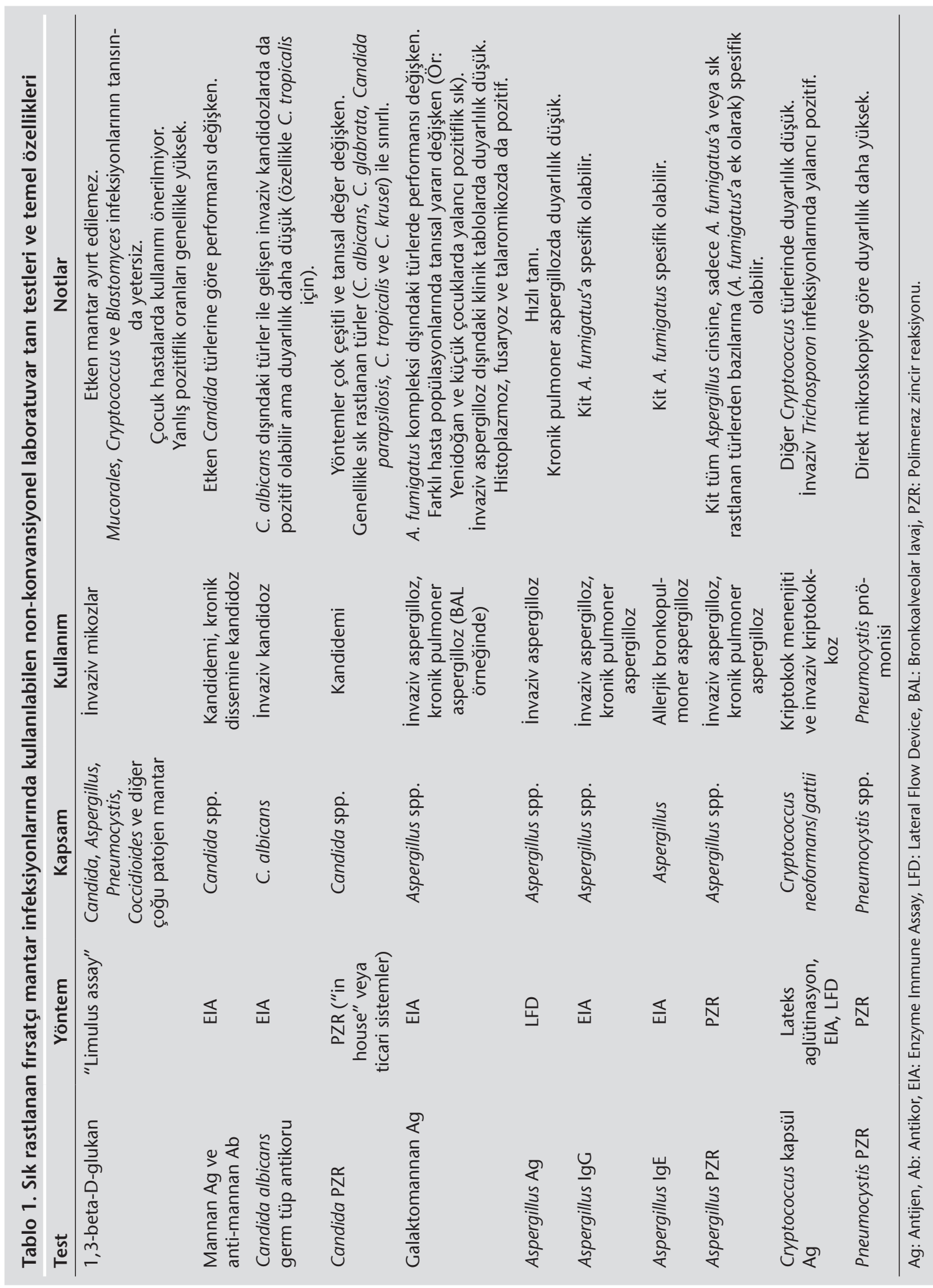


negatiflikler görülebilmektedir. Türbidimetrik olarak LAL reaksiyonunu okuyan bazı testler, bu sorunları așmayı hedeflemiștir. Lot bazında kalibre edildiği için tek örnek calıșabilen; hemolitik, lipemik ve ikterik örneklerden etkilenmeden sonuc verebilen ticari testler piyasada bulunmaktadir ${ }^{[17,33]}$. Pozitif sonuc için eșik değer yaygın kullanılan ticari kitler için $80 \mathrm{pg} / \mathrm{mL}$ olarak belirlenmiștir; ancak, farkl kitlerde değișiklik gösterebilmektedir ${ }^{[32,34]}$. Örneklerin antifungal tedavi öncesinde alınması ve optimum sonuç için tanı/tarama amacıyla kullanımda haftada iki kez, tedavi yanitının monitörizasyonunda haftada bir kez test yapilması ve pozitif sonucun kesinleștirilmesi için aynı örnekte veya yeni bir örnekte test tekrarı önerilmektedir ${ }^{[32,35]}$.

Pnömosistoz dișındaki invaziv mikozların tanısı için 1,3-beta-D-glukan testinin sonuçlarını inceleyen bir meta-analizde duyarlılı \%76.8 ve özgüllük \%85.3 bulunmuștur ${ }^{[34]}$. Kandidemi, invaziv kandidoz ve kronik dissemine kandidoz tanısı için haftada iki kez serumda test edilmesi önerilmektedir ${ }^{[10,32]}$. Kandidemi tanısında coğu çalıșmada duyarlılık \%65'in, özgüllük ise \%80'in üzerinde bulunmus, negatif prediktif değer >\%85 olarak hesaplanmıștır ${ }^{[10]}$. Aspergillus infeksiyonlarında hasta popülasyonuna ve klinik tabloya göre testin yararı değișken olsa da tanı ve tarama amaçl kullanılabilmektedir. Galaktomannan ve/veya $A s$ pergillus polimeraz zincir reaksiyonu (PZR) ile kombine kullanımının özgül tanıya daha cok yardımcı olduğu belirtilmiștir ${ }^{[11]}$.

Pneumocystis pnömonisinde de yüksek 1,3-beta-D-glukan düzeyleri saptanabilmektedir ${ }^{[20]}$. Kolorimetrik ve türbidimetrik yöntemle sonuc veren iki testi karșlaștıran bir calıșmada sırasıyla duyarlılık $\% 85$ ve $\% 78$, özgülliuk ise $\% 87$ ve $\% 98$ bulunmuștur [33]. Bașka bir meta-analiz, Pneumocystis pnömonisi tanısı için 1,3-beta-D-glukan düzeyleri kullanan 23 calıșmayı değerlendirmiș, \%91 duyarlllık ve \%79 özgüllük bildirmiștir. Bu çalıșma, HIV pozitif hasta popülasyonunda duyarlılığın daha yuiksek olduğunu belirterek (HIV pozitif hastalarda \%94 iken HIV negatiflerde \%86) testlerin tanisal değerlerinin belirlenmesinde hasta popülasyonunun önemine dikkati cekmiștir ${ }^{[36]}$. Ülkemizden bir çalıșma ise; pnömosistoz tanısında direkt floresan mikroskopi altın standart olarak alındığında 1,3-beta-D glukan testinin duyarlılığını \%100, özgüllüŭünü ise \%93.9 olarak bildirmiștir [37]
Fusaryozda 1,3-beta-D glukan testi pozitif olabilmekte, tedavi takibinde de kullanilabilmektedir ${ }^{[8]}$. Brezilya'dan bir calıșma 2000-2018 arasında tespit edilen 17 fusaryoz olgusunu aynı dönemdeki nötropenik ates olguları ile karșılaștırmıștır. Ardıșk iki test ile yüksek duyarlılık (\%85), özgüllük (\%69) ve negatif prediktif değer (\%99) bulunmus ve klinik bașlamadan önce testin pozitifleșebildiği gözlenmiștir. Ancak, düșük pozitif prediktif değerin (\%7) erken dönemde tanısal değeri kısıtladığı düșünülmüștür [38].

Hücre duvarı beta-glukan içeren ama nadir olarak etken olan mantarlara bağlı infeksiyonlarda 1,3-beta-D-glukan testinin tanısal değeri için elimizde yeterli veri bulunmamaktadir.

\section{Galaktomannan}

Galaktomannan antijeninin serumdaki titresinin belirlenmesinin ve ardișk örneklerde titrede artış saptanmasının invaziv aspergillozun erken tanısında kullanılabileceğine ilișkin veriler elde edilmiștir. Bağıșıklık sistemi baskılanmıs hasta popülasyonlarında (nötropeni, hematolojik malignite, kemik iliği veya solid organ transplantasyonu varlığı, kortikosteroid ve benzer bağıșıklık sistemi baskılayıcı tedaviler gibi) invaziv aspergillozun prospektif taramas1, tanıs1 ve tedavi takibinde önerilmektedir ${ }^{[11,16,31]}$. Farklı hasta gruplarında testin tanısal performansı değișebilmektedir. Örneğin nötropenik hastalardaki duyarlılığın nötropenik olmayanlara göre daha yüksek olduğu belirtilmektedir ${ }^{[11,16]}$.

İnvaziv aspergillozun hizlı tanısında serum, BAL, BOS ve akciğer dokusu örneklerinde galaktomannan antijeni saptanabilmektedir ${ }^{[11,16,31]}$. Yüksek risk grubundaki hastalarda, haftada en az iki kez serum örneğinin test edilmesi durumunda tanıya katkıda bulunduğu gösterilmiștir ${ }^{[11]}$. İnvaziv aspergilloz süphesinin yüksek olduğu hastalarda, serum örneklerinde galaktomannan negatif bulunduğunda, BAL örneklerinin test edilmesi önerilmektedir ${ }^{[16]}$. Serum örneklerinde düșük olan duyarlılık, uygun eșik değerleri kullanıldığında BAL örneklerinde \%100'e ulașabilmektedir ${ }^{[39,40]}$. Antifungal profilaksi veya tedavi alan hastalarda serum ve BAL örneklerinden elde edilen galaktomannan düzeyleri için verinin sinırlı olması ve eșik değerlerinin kesinleșmemiș olması nedeniyle değerlendirmesinde dikkatli olunmalıdır ${ }^{[16]}$. Serebral aspergilloz tanısında BOS örneklerinde 
galatomannan tespiti önerilmektedir; ancak, valide edilmiș eșik değerleri bulunmamaktadır ${ }^{[11]}$. Galaktomannan, akciğer biyopsilerinde de test edilebilmekle birlikte, elde yeterli miktarda doku olması önemlidir ${ }^{[11]}$. Test edilecek örnek için kullanılan galaktomannan kitinin valide edilmis olmasına dikkat edilmelidir. Antifungal tedavinin etkinliğinin anlașılmasında galaktomannan düzeyinin takibi kanser hastalarında yararlı olabilmektedir. Bu hasta grubunda antifungal tedavinin ilk iki haftasında serum galaktomannan değerlerinde azalmanın tedavi bașarısı ile uyumlu olduğu belirtilmiștir ${ }^{[11]}$. Ancak, test sonuçlarının güvenilirliğini etkileyen çeșitli değișkenler bulunmaktadır. Testin ilk versiyonlarında piperasilin/tazobaktam tedavisi altında saptanan yalancı pozitiflik sorunu son çalısmalarda bildirilmemekle birlikte; kan transfüzyonları, kan ürünü infüzyonları, mantar kökenli antibiyotiklerin kullanımı ve bazı glukan içeren besinlerin tüketimi sonrası sorun devam etmektedir ${ }^{[11,16,41]}$. Ayrıca histoplazmoz, fusaryoz ve talaromikoz gibi diğer mantar infeksiyonlarında da pozitiflik gözlenebilmektedir ${ }^{[1,16]}$. Pediatrik hastalarda erișkine benzer olarak yüksek duyarlılık ve özgüllük bildirilmișse de, yenidoğan ve küçük bebeklerde yalancı pozitiflik daha sı görülmektedir. Bu durumdan barsak mikrobiyotasındaki bifidobakteriler sorumlu tutulmaktadır ${ }^{[31]}$. Ülkemizden bir calıșmada, hematolojik malignitesi olan 1-16 yas arasındaki çocuk hastalarda invaziv aspergilloz tanısında farklı eșik değerler kullanılarak galaktomannan testinin yeri araștırılmıștır. Pozitif prediktif değer, en yüksek eșik değer (galaktomannan indeksi > 1.5) kullanıldığında bile tek örnek pozitif olan hastalarda \%50 iken, iki ardıșık örnekte pozitiflik saptandığında \%100'e ulașmıștır [42].

Galaktomannan antijeni, invaziv aspergilloz dıșında Aspergillus'un etken olduğu diğer klinik tabloların tanısında aynı performansı gösterememektedir. Örneğin, kronik pulmoner aspergilloz tanısında serum galaktomannan duyarlılığı düșük bulunduğundan BAL örneklerinin test edilmesi önerilmekte, buna karșın duyarlılik yine düșük kalabilmektedir ${ }^{[29,43]}$. Aspergillus'un etken olduğu fungal sinüzitte ise, patolojik olarak kesin tanı almıs hastalarda serum galaktomannan testinin özgülliüğünün yüksek ama duyarlılığın oldukça düșuik olduğu bildirilmiștir ${ }^{[44]}$.

\section{Aspergillus Spesifik Antijen ve Antikor Testleri}

Aspergillus antijeni "lateral flow device" (LFD) ile BAL ve serum örneklerinde tespit edilebilmektedir $^{[11]}$. Otuz dakika gibi kısa bir sürede sonuc vermesi invaziv aspergilloz tanısında avantaj sağlamaktadır. Ancak, duyarlılığı invaziv aspergillozda bile, hasta bașında uygulanabilmesi için serum veya BAL örnekleri ön ișleme alınmadan test edildiğinde azalmaktadır ${ }^{[45]}$. Ayrıca, galaktomannan antijenine benzer sekilde, farklı klinik tablolarda performansı değișmektedir. Kronik aspergillozda BAL örneklerinde yaklașı \%10 gibi cok düșük duyarlılık oranları bildirilmiștir ${ }^{43]}$. Yüksek özgülliük değerleri, negatif prediktif olarak kullanılmasına olanak vermektedir.

Aspergillus spesifik antikorları, presipitan antikorlar ve aglutine edici antikorlar invaziv aspergilloz ile kronik aspergilloz tablolarının tanı/ ayrımında kullanılabilmektedir. Bunun için farklı yöntemlerle çalısan ticari sistemler bulunmaktadır ${ }^{[11]}$. Tanı için daha cok IgG tipi antikorlar anlamlı bulunmustur. IgM ve IgA tipi antikorların tanısal değeri sınırlıdır. Aspergillus IgE tespiti, alerjik bronkopulmoner aspergilloz (ABPA) tanı kriterleri arasinda yer almaktadir ${ }^{[29]}$

\section{Mannan ve Antimannan}

Candida antijenlerinin hastalı tanısında kullanımında; kandaki düzeyin düșuik olması, kandan hızla temizlenmeleri, oluşan antijen-antikor komplekslerinin değerlendirmeyi güçleștirmesi ve mikrobiyotada Candida türlerinin yaygın olarak bulunmalarının yalancı pozitifliklere neden olabilmesi sorun yaratmaktadır ${ }^{[15,46]}$. Tanıda, mantar hücre duvarı yapisinda bulunan 1,3-beta-D glukan ve mannan antijenleri en basarilı hedefler olarak öne çkmıșlardır ${ }^{[15,17]}$. Mannan antijeni, lateks aglütinasyon veya enzim "immunoassay" (EIA) ile tespit edilebilmektedir ${ }^{[15]}$. Lateks agluitinasyon testinin kantitatif olmaması ve duyarlılığının özgül antikorların varlığından etkilenmesi ek bir dezavantaj getirmektedir ${ }^{[47]}$.

Candida antijenlerine karșı gelișen antikorların tanıda kullanımı da antikor olușumunun zaman gerektirmesi, yüksek riski olan immünkompromize hasta grubunda baskılanmıs olması ve geçirilmiş infeksiyonu veya kolonizasyonu ayırt edememesi 
nedeniyle sınırlanmaktadır ${ }^{[15,17]}$. Genellikle, mannan antijenine karșı gelișen IgG tipi antikorların araștırılması daha bașarılı sonuçlar vermiștir ${ }^{[17,46]}$. Ancak; invaziv kandidozu olan hastalar, Candida kolonizasyonu saptanan kișiler ve kontrol grubu kullanılarak invaziv kandidoz tanısında antimannan antikorlarının tanısal değerini araștıran bir calıșmada duyarlılık ve özgülliük IgG için daha düșük (sırasıla \%68-75 ve \%91-94), IgM içinse yüksek (sırasıyla \%78-80 ve \%97-98) bulunmustur. IgG ve IgM sonuçlarının kombine değerlendirilmesiyle duyarlılığın arttığı belirtilmiștir[48]. Ayrıca, farkl Candida türlerinde antikor yanıtı değișebilmektedir. Bir calıșma, kandidemilerde etkenin C. krusei olduğu durumlarda, C. tropicalis'e göre anlaml olarak daha yüksek antimannan IgG değerleri saptamıștır $^{[46]}$. Bu calıșmalar, antimannan antikor testlerinin daha ayrıntılı incelenmesinin gerekliliğine ișaret etmektedir.

Tek bașına kullanıldıklarında yeterli duyarlılık ve özgülluik düzeylerine ulașamayan mannan ile antimannan antikoru, eszamanlı test edildiklerinde invaziv kandidoz tanısında yararlı olabilmektedirler ${ }^{[10,17,46,49]}$. Kandidemide ve kandidemi olmadan derin yerleșimli kandidozlarda tanisal testlerin performansı değișkenlik göstermektedir[10]. Mannan ve antimannan testleri için FDA onayı bulunmadığından ABD'de kandidoz tanısında kullanımı sinırlıdır ${ }^{[17]}$. Avrupa'da ise, ESCMID Candida infeksiyonları için tanı kılavuzunda eșzamanl mannan ve antimannan tespitinin kandidemi ve kronik dissemine kandidoz tanısında öneriler arasında bulunması nedeniyle daha yaygındır. Ardıșı testlerin tanıda bașarıyı artırabileceği de belirtilmiștir. Ancak, invaziv kandidoz tanısında öneriler arasında bulunmamaktadır. Kandidemi içinduyarlılık ve özgülliuğuin sırasıyla yaklașık \%80 ve \%85 olduğu bildirilmiștir. Kan kültüründeki üremeden ortalama altı gün önce pozitiflik saptanabilmesi önemli bir avantaj olarak öne clkmaktadır ${ }^{[10]}$. Mannan/antimannan kombinasyonunun C. albicans, C. glabrata ve $C$. tropicalis infeksiyonlarının tanısında daha bașarılı olduğu bildirilmiștir [17]

Mannan ve antimannan tespiti için EIA tercih edilen calıșmalarda daha cok Platelia Ag ve $\mathrm{Ab}$ (BioRad, Fransa) veya bu kitlerin bir sonraki versiyonu olan Platelia $\mathrm{Ag}$ ve $\mathrm{Ab}$ Plus (BioRad, Fransa) kitleri kullanılmıstır. Mannan ve antimannan testlerinin etkinliği daha cok eski nesil testlerle belirlenmiștir ${ }^{[10]}$. Kitlerin eski ve yeni versiyonlarını az sayıda hasta örneği ile karșlaștıran ilk calıșma antijen testinde özgüllüğün yeni versiyonda $\% 50$ azaldığını bildirmis ve bu durumun yuizeyel Candida infeksiyonlarından kaynaklanabileceği yorumunu yapmıștır ${ }^{[50]}$. Ancak, yüzeyel kandidozlu hastaların dahil olduğu bir calıșmada Platelia Ag Plus kiti ile yalancı pozitiflik görülmemiștir ${ }^{[49]}$. Ayrıca, daha yakın zamanlı bir çalıșmada yeni versiyon ile elde edilen sonuçarın daha duyarlı (\%65'e \%85), özgüllükteki düșusüün de sinırlı (\%98'e \%89) olduğu bildirilmiștir ${ }^{[51]}$. Mannan/antimannan testlerinin diğer biyobelirteclerle birlikte izlemi, antifungal tedavi alan hastalarda mortaliteyi artırmadan tedavinin daha erken kesilmesine olanak taniyabilmektedir. Ancak, bu yaklașımın ayrıntıları netleșmemiș ve henüz kılavuzlara öneri olarak girmemiștir ${ }^{[35]}$.

Candida fosfopeptidomannanına karș1 gelișen IgG2 tipi antikorların tespitinin invaziv kandidoz ile kolonizasyon ayrımında yararlı olabileceği iddia edilmișse de, diğer Ig alt sınıfları ile bir karșılaștırma yapılmamıștır ${ }^{[15]}$.

\section{Candida İçin Özgüil Serolojik Testler}

C. albicans germ tüp antikoru testi, invaziv kandidoz tanısı için geliștirilmeye calıșılmış; ancak, yoğun kolonizasyon gözlenebilen yoğun bakım hastalarında özguilliü̆uin azaldığı belirtilmiștir ${ }^{[16]}$. Özgüllük ve duyarlılık, farklı calıșmalarda büyük değișkenlik göstermektedir. C. albicans dıșındaki türlerle gelișen infeksiyonlar tespit edilebilse de, etken olan Candida türü de test sonucunu etkilemektedir. Derin yerleșimli Candida infeksiyonu saptanmayan kandidemilerde de duyarlılığın düșük olduğu öne sürülmüștür ${ }^{[17]}$. Mannan veya 1,3-beta-D-glukan testleri ile kombine kullanımları tanıda bașarılarını artırabilmektedir ${ }^{[15]}$.

Candida'ya özgü protein antijenleri tespit etmeye yönelik lateks aglütinasyon veya EIA yöntemleri de bulunmaktadir. Bu testlerin duyarlılik ve özgüllükleri düșük bulunmus ve tanıda rutin olarak kullanımları önerilmemiștir ${ }^{[15,47,49] \text {. }}$

\section{Cryptococcus Kapsiul Antijeninin Saptanması}

En yaygın kullanılan antijen saptama testlerinden biri kriptokok infeksiyonu tanısında uygulanan 
antijen testidir. Kriptokok kapsül antijeni, serumda ve BOS'ta lateks aglütinasyon, enzim immünoassay ve "lateral flow" yöntemiyle saptanabilmektedir. Duyarlılığının direkt mikroskopiden yüksek olmas1 tercih sebebidir ${ }^{[7,52]}$. Sistemik Trichosporon infeksiyonlarında yanlıs pozitiflik gözlenebilmekteyse de, nadir rastlanan bir durum olması nedeniyle genellikle sorun yașanmamaktadir ${ }^{[7,53,54]}$. Cryptococcus kapsül antijeni tespiti için geliștirilen yöntemler öncelikle Cryptococcus neoformans/gattii'yi hedefleyerek geliștirildiğinden diğer türlerde duyarlılık düșüktür ${ }^{[53]}$. Kriptokok menenjiti olan hastalarda serum veya BOS'ta kapsül antijeni titresinde azalma tedavi bașarısına ișaret etmekle birlikte, azalmanın bir haftadan fazla gecikebildiŏi akılda tutulmalıdır ${ }^{[18]}$. Bağıșılılı̆ın düzelmediği durumlarda ömür boyu sürebilen antijen pozitifliği ve tedavi gereksinimi olabilmektedir. Antijen pozitifliği, klinik düzelmeden ve hastanın iyileșmesinden sonra da gözlenebilmektedir. Ayrıca; HIV pozitif hastalarda klinik hastalık gelișmeden haftalar önce antijen pozitifliği saptanabilmekte, bu hastalarda preemptif flukonazol tedavisi kriptokok menenjiti gelișimini engelleyebilmektedir ${ }^{[52]}$.

\section{Endemik Mikoz Etkeni Mantarlar İçin Antijen ve Antikor Saptama Testleri}

Histoplazmoz tanısinda serum, idrar veya BAL'da özgül antijen ve/veya antikor saptanması, altın standart olmasına karșin zaman alıcı olan kültür yöntemine tercih edilebilmektedir. Antijen testinin, dissemine ve diffüz akut pulmoner histoplazmoz tanısında özel bir yeri vardır. Daha düșük antijen miktarlarını saptayabilen kantitatif testlerin geliștirilmesi özgüllüğü artırmıștır. Diğer endemik mikozlarla capraz reaksiyon görülebilmesine karsın duyarlılık \%81, özgülliuk ise \%98'lere ulașabilmektedir. Histoplasma antijen ile antikorunun eszamanlı test edilmesi duyarlılığı artırabilmektedir. İdrar ve serum örneklerinin birlikte çalıșılmasının yararlı olabileceğine dair sınırlı veri bulunmaktadır. Antikor testlerinin duyarlılığının immün sistemi baskılanmıș hastalarda düșük olduğu da akılda tutulmalidir ${ }^{[16]}$.

Blastomikoz ve koksidiyoidomikoz gibi diğer endemik mikozlarda da antijen ve antikor saptama testleri tanıda yararlı olabilmektedir. Histoplazmoz olgularındakine benzer sekilde, antikor saptama testleri immünkompetan hastalarda daha bașarılı bulunmuștur [16].

\section{Nuikleik Asit Temelli Tanı Testleri}

Etkene özgü nükleik asit amplifikasyonu için PZR kullanan testlerin yanı sıra, nükleik asit probları kullanan hibridizasyon testleri de infeksiyon hastalıklarının tanısında bașarı ile kullanılmaktadır. En önemli avantajları, testin doğası gereği örnekte az miktarda nükleik asit bulunduğunda bile özgül olarak tespit etme potansiyelleridir. Ancak mantarlara özgü bazı sorunlar nedeniyle henüz rutin laboratuvarda tanı için önerilen testler sinırlıdır. Mantar hücrelerindeki sağlam ve polisakkaritten zengin hücre duvarı, klinik örneklerde konak materyaline göre az miktarda bulunan etken mantarin DNA'sının yeterli miktarda ve uygun saflıkta elde edilmesini gücleștirmektedir. Hedeflenen gen bölgesi de belirli türlere/cinslere özgü veya "panfungal" olabilmektedir. Hastalık etkeni mantarların çŏ̆unun hastanın mikrobiyotasında bulunabilmesi nedeniyle, test sonucunun hastalik lehine yorumlanabilmesi için eșik değerleri belirlenmiș kantitatif test sonuçları gerekli olabilmektedir. Ayrıca, mantarların doğada yaygın olarak bulunmaları, örneğin kontaminasyondan korunması için ek önlemlerin alınmasını zorunlu kılmaktadır[6,7,15]. Tüm bu sorunlara karssın, tanıda yarar sağlayan ve kullanımı önerilen nükleik asit temelli testler bulunmakta ve test geliștirme cabaları devam etmektedir.

\section{Aspergillus PZR}

Aspergillus PZR testinin invaziv aspergillozda galaktomannan ile birlikte kullanımı daha erken ve daha kesin tanıya yardımcı olabilmektedir ${ }^{[11]}$. Uzun süreli nötropenisi olan hematolojik malignite hastaları, küf profilaksisi almayan allojenik kemik iliği nakli hastaları ve riskli yoğun bakım hastaları gibi bazı gruplarda BAL, tam kan ve serumda çalıșlması önerilmektedir. Merkezi sinir sistemi tutulumu veya menenjit süphesi varsa BOS örneklerinde calıșlabilmektedir ${ }^{[11]}$. Ülkemizden bir çalıșma, nötropenik olmayan yoğun bakım hastalarında invaziv aspergilloz tanısında BAL örneklerinde Aspergillus PZR'ın duyarlılığını düșük (\%40.0), özgülluiğuinü yüksek (\%93.9) bulmuștur ${ }^{[39]}$. Bașka bir calıșma ise nötropenik hastalarda invaziv aspergilloz tanısı için serum örneklerinde duyarlılığı \%30 olarak bildirmiștir ${ }^{[40]}$. Ayrıca, DNA ekstraksi- 
yonunun daha yüksek hacimde (>500 $\mu \mathrm{L})$ serum örneği kullanılarak yapılmasının test performansını artırabileceği belirtilmiștir ${ }^{[55]}$.

Kronik pulmoner aspergillozda duyarlılığın kültürden daha iyi olduğu bildirilmiștir ${ }^{[29]}$. Ayrıca, doku örneklerinde (taze doku veya parafine gömülü doku) uygulanabilmektedir. Mikroskopi ile hif görülen örneklerde duyarlılık daha yüksektir ${ }^{[11]}$. Pediatrik hastalardaki calıșmalar sınırlıdır ve henüz kullanımına yönelik öneri geliștirilememiștir ${ }^{[31]}$. $\mathrm{Bu}$ amaçla geliștirilen ticari kitler, ağırlıklı olarak en sik rastlanan patojen tür olan Aspergillus fumigatus kompleksini hedeflemektedir ve diğer türleri tespit etmekteki bașarıları değișkendir [56]. Bazı kitlerde, Aspergillus cinsinde artmaya basslayan azol direncini tespit etmeye yönelik mutasyon taramaları da yapilabilmektedir ${ }^{[57]}$

\section{Candida PZR}

Kandidemi tanısında kan kültürü duyarlılığ1nın düsüuk olması nedeniyle, Candida türlerinin kan örneklerinden tespiti ve/veya tanımlanması için cok sayida "in-house" ve ticari kit bulunmaktadır ${ }^{[10,17]}$. Bunlardan bazıları, sık rastlanan bakteriyemi etkenlerini de içerebilen coklu PZR testleridir. Çoğu test, klinik örneklerde sık rastlanan Candida türleri ile sinırlıdır ${ }^{[17]}$. Bu testlerin özgüllükleri, özellikle yoğun Candida kolonizasyonu gözlenen yoğun bakım hastalarında olumsuz etkilenebilmektedir ${ }^{[16]}$. Kan kültürü ile karșılaștırıldığında duyarlılık değerlerinin yüksek olması ve daha kısa zamanda sonuc vermeleri nedeniyle umut verici olduklarını bildiren calıșmalar bulunmaktadir ${ }^{[58]}$. Ancak, testlerin yöntemsel olarak büyük değișkenlik gösterdiği ve coğunun sık gözlenen bazı Candida türleri (C. albicans, C. glabrata, Candida parapsilosis, $C$. tropicalis ve $C$. krusei) ile sınırlı olduğu hatırlanmalıdır ${ }^{[17]}$.

Candida invaziv infeksiyonlarının tanısında PZR ve manyetik rezonans testlerini birlestiren "T2 Candida Magnetic Resonance Assay" kullanılabilmektedir $^{[7,15,17]}$. Bu test, tam kan örneğinden sık görülen bes Candida türünü (C. albicans, C. glabrata, C. parapsilosilosis, C. tropicalis, C. krusei) 5 saat içinde saptayarak tür bazında raporlayabilmekte; ancak, kendine özgü bir cihaz (T2DX) gerektirmektedir ve ${ }^{[17]}$ bu testin FDA onayı bulunmaktadir.

\section{Pneumocystis PZR}

Pneumocystis rutin mikrobiyoloji laboratuvarlarında kültuirde üretilemeyen bir patojen olduğundan tanısında direkt immünfloresan boyama ile mikroskopi tercih edilmektedir. $\mathrm{Bu}$ amaçla gönderilen solunum yolu örneklerinin gerektiğinde $n$-asetil sistein veya sputolizin ile homojenize edilmesi önerilmektedir ${ }^{[18]}$. Ancak, mikroskopinin düșük duyarlılığı farklı arayıșlara neden olmuștur. Son yıllarda Pneumocystis için özgül PZR yöntemleri ile \%90 civarında duyarlılık ve özgüllük bildirilmesi umut verici olmuștur ${ }^{[14,20,37]}$

\section{Diğer Patojenlere Yönelik PZR Testleri}

Farklı hastalık etkeni mantarlara özgül PZR testleri de geliștirilmiș ve yararlı olabildikleri bildirilmiștir. Hızlı tanının hastanın sağ kalımı için kritik olduğu Mucorales takımına ait küf mantarlarının etken olduğu infeksiyonlarda tanı, mikroskopi, kültür ve görüntüleme tekniklerine dayanmaktadır. Mucorales takımına özgül veya içindeki cinsleri hedef alan PZR yöntemleri, erken ve kesin tanıya olanak sağlayabilmektedir ${ }^{[59,60]}$. Nadir görülen ama yüksek mortaliteye neden olan invaziv Fusarium infeksiyonlarının tanısında farklı PZR yöntemleri ile değișken özgüllük ve duyarlılık oranları bildirilmiștir ${ }^{[8]}$. Endemik mikozlara yönelik çalıșmalar da yapılmaktadır. Blastomyces için PZR kullanan merkezler bulunmaktadir ${ }^{[16]}$. Dermatofitoz tanısında da, doğrudan klinik örnekten calıșılan PZR testleri tanıda zaman kazandırabilmekte ama çoğu merkezde maliyet nedeniyle uygulanmamaktadır $^{[13]}$. Bu amaçla belirli bir tür dermatofiti, tüm dermatofitleri veya tüm mantarları hedefleyen primerler kullanılabilmektedir. Daha genel primerler kullanıldığında dizi analizi ile cins/tür düzeyinde tanımlama yapilabilmektedir. Bu durum, özellikle nadir görülen etkenlerle gelișen onikomikozlar gibi durumlarda avantaj sağlamaktadır.

\section{Çoklu ve "Panfungal” PZR Yöntemleri}

İnvaziv mikozların buiyük coğunluğunda kısıtlı sayıda tür etken olsa da, nadir görülen patojenler gittikçe daha cok karșımıza cıkmaktadır. Bu nedenle, etkene özgü PZR yöntemlerinin kısıtlılığını așmak için, coklu ("multiplex") ve "panfungal" teknikler geliștirilmektedir. Bu sayede invaziv mikoz tanısının konması/dıslanması, kültürde üretilemeyen etkenlerin cins ve tür düzeyinde tanımlan- 
ması hatta bazı durumlarda antifungal duyarlilikla ilgili bilgi elde edilebilmesi amaçlanmaktadır. Coklu PZR yöntemlerinde birden fazla patojene yönelik özgül primerler kullanılmakta, etkenler amplikon uzunluğu veya erime eğrisi analizi ile ayrilabilmektedir. "Panfungal" testlerde, tüm mantar kaynaklı nükleik asitleri amplifiye etmeye yönelik primerler kullanılmaktadır. Amplikon elde edildiğinde saflaștırılarak dizi analizi yapilabilmekte ve etken tanımlanmaktadır. Bu sayede nadir rastlanan patojenlerin cins/tür düzeyinde tanımlanabildiği de gözlenmiștir ${ }^{[13,61,62]}$. Gerçek zamanlı PZR yönteminde "panfungal" primerlere etkene özgü tasarlanmıs problar eklenmesi de mümkündür. Bu sayede, problar sik rastlanan patojenlerin erime eğrisi analizi ile tanımlanmasına olanak sağlamakta, diğer patojenler amplikon dizisinin analizi ile tanımlanabilmektedir ${ }^{[63]}$. Klinik örneklerden mantar DNA'sının ekstraksiyonundaki güçükler nedeniyle genellikle duyarlılı düșük, ancak özgüllük yüksek olarak bildirilmiștir [61-63].

\section{Diğer Yöntemler}

Mantar infeksiyonlarının tanısında kullanılmak üzere geliștirilmeye calıșlan farklı yöntem temelli testler de bulunmaktadir. Bunlar arasında "in situ hibridizasyon", "microarray" ve proteom temelli testler sayılabilir ${ }^{[7,15]}$. Genis spektrumlu PZR reaksiyonu ürünlerini iyonizasyon-kütle spektrometrisi ile birleștiren bir yöntem tanımlanmıștır ${ }^{[15,64]}$. Serolojik proteom analizi, rekombinant cDNA ekspresyon kütüphaneleri ve antijenik protein "microarray" gibi deneysel așamadaki yöntemler ile mantar infeksiyonlarının tanısında kullanılabilecek biyobelirtec arayıșı sürmektedir ${ }^{[15]}$.

$\mathrm{Bu}$ testlerin tanıya katkısını değerlendirirken, ilgili merkezdeki invaziv mikoz prevalansını ve çeșitliliğinin göz önüne alınması gerekmektedir. Ayrica, her mantar cinsi veya türünün kapsanmayabileceği akılda tutulmalıdır. Bu testlerin rutin laboratuvarda kullanımına yönelik elde yeterli veri bulunmamaktadir ${ }^{[10,11,15]}$.

\section{SONUÇ}

Mantar infeksiyonlarının tanısı için geliștirilen testler, halen mükemmel tanı sağlamaktan uzaktır. Coğu hastalık etkeni mantarın konakta ve çevrede sıklıkla bulunması nedeniyle kolonizasyon/ infeksiyon hatta kontaminasyon ayrımı güçleșmek- tedir. Özellikle invaziv mantar infeksiyonları için risk tașıyan farklı hasta popülasyonlarında konağa özgü durumlar testlerin performansını etkileyebilmektedir[6]. Geliștirilen yeni yöntemler ile daha erken dönemde kesin tanı konabilmesi için ilerleme sağlanmıș olsa da, özellikle nadir rastlanan etkenlerde yöntemlerin etkinliği henüz tam olarak ortaya koyulamamıștır. Konvansiyonel testler her durumda önerilmekte, es zamanlı olarak birden fazla non-konvansiyonel testin kullanımı tanı sansını artırmaktadır. Her durumda, test sonuçlarının yorumlanmasında konağın klinik durumunun değerlendirilmesi önemini korumaktadır.

\section{ÇIKAR ÇATIŞMASI}

Yazarlar bu makale ile ilgili herhangi bir çkar catıșması bildirmemiștir.

\section{KAYNAKLAR}

1. Kohler JR, Casadevall A, Perfect J. The spectrum of fungi that infects humans. Cold Spring Harb Perspect Med 2014;5:a019273.

2. Richardson M, Lass-Florl C. Changing epidemiology of systemic fungal infections. Clin Microbiol Infect 2008; 14(Suppl 4):5-24.

3. Cole DC, Govender NP, Chakrabarti A, Sacarlal J, Denning $D W$. Improvement of fungal disease identification and management: combined health systems and public health approaches. Lancet Infect Dis 2017;17:e412-e9.

4. Bongomin F, Gago S, Oladele RO, Denning DW. Global and multi-national prevalence of fungal diseases-estimate precision. J Fungi (Basel) 2017;3.

5. Hilmioglu-Polat S, Seyedmousavi S, Ilkit M, Hedayati MT, Inci $R$, Tumbay $E$, et al. Estimated burden of serious human fungal diseases in Turkey. Mycoses 2019;62:22-31.

6. Wickes BL, Romanelli AM. Diagnostic mycology: Xtreme challenges. J Clin Microbiol 2020;58.

7. Walsh TH, Hayden TH, Larone DH. Larone's Medically Important Fungi: A Guide to Identification. $6^{\text {th }}$ ed. Washington DC: ASM Press, 2018.

8. Tortorano $A M$, Richardson $M$, Roilides $E$, van Diepeningen A, Caira M, Munoz P, et al. ESCMID and ECMM joint guidelines on diagnosis and management of hyalohyphomycosis: Fusarium spp., Scedosporium spp. and others. Clin Microbiol Infect 2014;20(Suppl 3):27-46.

9. Guarner J, Brandt ME. Histopathologic diagnosis of fungal infections in the $21^{\text {st }}$ century. Clin Microbiol Rev 2011;24:247-80.

10. Cuenca-Estrella $M$, Verweij $P E$, Arendrup MC, Arikan-Akdagli S, Bille J, Donnelly JP, et al. ESCMID* guideline for the diagnosis and management of Candida diseases 2012: diagnostic procedures. Clin Microbiol Infect 2012;18(Suppl 7):9-18. 
11. Ullmann AJ, Aguado JM, Arikan-Akdagli S, Denning $D W$, Groll AH, Lagrou K, et al. Diagnosis and management of Aspergillus diseases: executive summary of the 2017 ESCMID-ECMM-ERS guideline. Clin Microbiol Infect 2018;24(Suppl 1):e1-e38.

12. Karcioglu O, Dogan R, Uzun O, Tokat F, Gulmez D, Arikan-Akdagli $S$, et al. A rare presentation of pulmonary aspergillosis: Bronchial stump aspergillosis. I Bronchology Interv Pulmonol 2020;27:e28-e33.

13. Petrucelli MF, Abreu MH, Cantelli BAM, Segura GG, Nishimura FG, Bitencourt TA, et al. Epidemiology and diagnostic perspectives of dermatophytoses. J Fungi (Basel) 2020;6.

14. Moodley B, Tempia S, Frean, JA. Comparison of quantitative real-time $P C R$ and direct immunofluorescence for the detection of Pneumocystis jirovecii. PLoS One 2017;12:e0180589.

15. Pitarch A, Nombela C, Gil C. Diagnosis of invasive candidiasis: From gold standard methods to promising leading-edge technologies. Curr Top Med Chem 2018;18:1375-92.

16. Hage CA, Carmona EM, Epelbaum O, Evans SE, Gabe LM, Haydour $Q$, et al. Microbiological Laboratory Testing in the Diagnosis of Fungal Infections in Pulmonary and Critical Care Practice. An Official American Thoracic Society Clinical Practice Guideline. Am / Respir Crit Care Med 2019;200:535-50.

17. Clancy CJ, Nguyen MH. Diagnosing invasive candidiasis. J Clin Microbiol 2018;56.

18. Hazen K, Howell SA. Mycology and Antifungal Susceptibility Testing, in Clinical Microbiology Procedures Handbook. In: Leber AL (ed). ASM Press: Washington DC, 2016.

19. Vergidis $P$, Moore $C B$, Novak-Frazer L, Rautemaa-Richardson $R$, Walker $A$, Denning DW, et al. High-volume culture and quantitative real-time $P C R$ for the detection of Aspergillus in sputum. Clin Microbiol Infect 2020;26:935-40.

20. Song $Y$, Ren $Y$, Wang $X, L i R$. Recent advances in the diagnosis of Pneumocystis pneumonia. Med Mycol 2016;57:E111-E116.

21. Gulmez D, Alp S, Gursoy G, Ayaz CM, Dogan O, Arikan-Akdagli $S$, et al. Mixed fungaemia: an 18-year report from a tertiary-care university hospital and a systematic review. Clin Microbiol Infect 2020;26:833-841.

22. Horvath LL, George BI, Murray CK, Harrison LS, Hospenthal DR. Direct comparison of the BACTEC 9240 and BacT/ ALERT 3D automated blood culture systems for candida growth detection. J Clin Microbiol 2004;42:115-8.

23. Arendrup MC, Bergmann OJ, Larsson L, Nielsen HV, Jarlov JO, Christensson B. Detection of candidaemia in patients with and without underlying haematological disease. Clin Microbiol Infect 2010;16:855-62.

24. Gokbolat $E, O z Y$, Metintas S. Evaluation of three different bottles in BACTEC 9240 automated blood culture system and direct identification of Candida species to shorten the turnaround time of blood culture. I Med Microbiol 2017;66:470-6.
25. Uyan A, Taşbakan M, Metin DY, Pullukçu H, Durusoy $R$, Hilmioglu-Polat S. Kandidürili hastalara yaklaşımda koloni sayısının önemi var mı? FLORA 2016;21:105-10.

26. Doğan $O, G u ̈ l m e z ~ D$, Arıkan Akdağı S. Fungemi olgularında hızı bir ön tanımlama testi: Pozitif kan kültürü șişesinden yapılan doğrudan germ tüp testinin değerlendirilmesi. ANKEM Derg 2016;30:102-8.

27. Dogan O, Inkaya AC, Gulmez D, Uzun O, Akova M, Arikan Akdagli S. [Evaluation of PNA-FISH method for direct identification of Candida species in blood culture samples and its potential impact on guidance of antifungal therapy]. Mikrobiyol Bul 2016;50:580-9.

28. Bal AM, McGill M. Rapid species identification of Candida directly from blood culture broths by Sepsityper-MALDI-TOF mass spectrometry: impact on antifungal therapy. I $R$ Coll Physicians Edinb 2018;48:114-9.

29. Denning DW, Cadranel J, Beigelman-Aubry C, Ader F, Chakrabarti $A$, Blot $S$, et al. Chronic pulmonary aspergillosis: rationale and clinical guidelines for diagnosis and management. Eur Respir J 2016;47:45-68.

30. Boch T, Spiess B, Cornely OA, Vehreschild JJ, Rath PM, Steinmann J, et al. Diagnosis of invasive fungal infections in haematological patients by combined use of galactomannan, 1,3-beta-D-glucan, Aspergillus PCR, multifungal DNA-microarray, and Aspergillus azole resistance PCRs in blood and bronchoalveolar lavage samples: results of a prospective multicentre study. Clin Microbiol Infect 2016;22:862-8.

31. Warris A, Lehrnbecher T, Roilides E, Castagnola E, Bruggemann RJM, Groll AH. ESCMID-ECMM guideline: diagnosis and management of invasive aspergillosis in neonates and children. Clin Microbiol Infect 2019;25:1096-13.

32. Wright WF, Overman SB, Ribes JA. (1-3)- $\beta$-D-glucan assay: A review of its laboratory and clinical application. Lab Medicine 2011;42:679-85.

33. Mercier T, Guldentops E, Patteet S, Beuselinck K, Lagrou $K$, Maertens J. Beta-d-glucan for diagnosing Pneumocystis pneumonia: a direct comparison between the Wako beta-glucan assay and the Fungitell assay. I Clin Microbiol 2019;57.

34. Karageorgopoulos DE, Vouloumanou EK, Ntziora F, Michalopoulos A, Rafailidis Pl, Falagas ME. beta-D-glucan assay for the diagnosis of invasive fungal infections: a meta-analysis. Clin Infect Dis 2011;52:750-70.

35. Bouza E, Almirante B, Garcia Rodriguez I, Garnacho-Montero J, Salavert M, Munoz P, et al. Biomarkers of fungal infection: Expert opinion on the current situation. Rev Esp Quimioter 2020;33:1-10.

36. Del Corpo O, Butler-Laporte G, Sheppard DC, Cheng MP, McDonald EG, Lee TC. Diagnostic accuracy of serum (1-3)-beta-D-glucan for Pneumocystis jirovecii pneumonia: a systematic review and meta-analysis. Clin Microbiol Infect 2020; 26(9):1137-43.

37. Tekinşen FF, Koç AN. Klinik örneklerde çeşitli yöntemlerle Pneumocystis jirovecii araştırılması. Mikrobiyol Bul 2013;47:658-67. 
38. Nucci M, Barreiros $G$, Reis $H$, Paixao M, Akiti T, Nouer SA. Performance of 1,3-beta-D-glucan in the diagnosis and monitoring of invasive fusariosis. Mycoses 2019;62:570-5.

39. Özger S, Hızel K, Kalkancı A, Aydoğdu M, Civil F, Dizbay M, et al. Nötropenik olmayan yoğun bakım hastalarında invazif pulmoner aspergilloz için risk faktörlerinin değerlendirilmesi ve bronkoalveoler lavaj örneklerinde galaktomannan ve PCR testlerinin tanısal değerinin belirlenmesi. Mikrobiyol Bul 2015;49:565-75.

40. Sav H, Koç N, Atalay MA, Yıldız O, Demir G. Sistemik aspergilloz tanısında çeşitli yöntemlerin araştırılması. FLORA 2014;19:66-73.

41. Walter W, Bornhauser M, Stolzel F, Knoth H. False-positive Candida and Aspergillus antigen testing in recipients of allogeneic haematopoietic cell transplantation due to administration of parenteral nutrition and fixed combinations of piperacillin-tazobactam. Mycoses 2019;62:576-83.

42. Çağlar I, Özkerim D, Tahta N, Düzgöl M, Bayram N, Demirağ $B$, et al. Assessment of serum galactomannan test results of pediatric patients with hematologic malignancies according to consecutive positivity and threshold level in terms of invasive aspergillosis diagnosis: Cross-sectional research in a tertiary care hospital. J Pediatr Hematol Oncol 2020;42:e271-e6.

43. Salzer HJF, Prattes J, Flick H, Reimann M, Heyckendorf J, Kalsdorf B, et al., Evaluation of galactomannan testing, the Aspergillus-specific lateral-flow device test and levels of cytokines in bronchoalveolar lavage fluid for diagnosis of chronic pulmonary aspergillosis. Front Microbiol 2018;9:2223.

44. Melancon CC, Lindsey J, Russell GB, Clinger JD. The role of galactomannan Aspergillus antigen in diagnosing acute invasive fungal sinusitis. Int Forum Allergy Rhinol 2019;9:606.

45. Metan G, Keklik M, Dinc G, Pala C, Yildirim A, Saraymen B, et al. Performance of galactomannan antigen, beta-d-glucan, and Aspergillus-lateral-flow device for the diagnosis of invasive aspergillosis. Indian / Hematol Blood Transfus 2017;33:87-92.

46. Wang K, Luo Y, Zhang W, Xie S, Yan P, Liu Y, et al. Diagnostic value of Candida mannan antigen and anti-mannan IgG and IgM antibodies for Candida infection. Mycoses 2020;63:181-8.

47. Herent P, Stynen D, Hernando F, Fruit J, Poulain D. Retrospective evaluation of two latex agglutination tests for detection of circulating antigens during invasive candidosis. J Clin Microbiol 1992;30:2158-64.

48. Meng $Y$, Kang $M$, Li D, Wang $T$, Kuang Z, Ma Y. Performance of a new Candida anti-mannan IgM and IgG assays in the diagnosis of candidemia. Rev Inst Med Trop Sao Paulo 2020;62:e25.

49. Held J, Kohlberger I, Rappold E, Busse Grawitz A, Hacker G. Comparison of (1->3)-beta-D-glucan, mannan/anti-mannan antibodies, and Cand-Tec Candida antigen as serum biomarkers for candidemia. J Clin Microbiol 2013;51:115864.
50. Lunel FM, Donnelly JP, van der Lee HA, Blijlevens NM, Verweij PE. Performance of the new Platelia Candida Plus assays for the diagnosis of invasive Candida infection in patients undergoing myeloablative therapy. Med Mycol 2011;49:848-55.

51. Hartl B, Zeller I, Manhart A, Selitsch B, Lass-Florl C, Willinger $B$. A retrospective assessment of four antigen assays for the detection of invasive candidiasis among high-risk hospitalized patients. Mycopathologia 2018;183:513-9.

52. Chammard TB, Temfack E, Lortholary O. Alanio A. Diagnostic and therapeutic strategies in cryptococcosis: impact on outcome. Mem Inst Oswaldo Cruz 2018;113:e180050.

53. Arendrup MC, Boekhout T, Akova M, Meis JF, Cornely OA, Lortholary O, et al. ESCMID and ECMM joint clinical guidelines for the diagnosis and management of rare invasive yeast infections. Clin Microbiol Infect 2014;20 (Suppl 3):76-98.

54. Alp S, Gulmez D, Ayaz CM, Arikan-Akdagli S, Akova M. Fungaemia due to rare yeasts in a tertiary care university centre within 18 years. Mycoses 2020;63:488-93.

55. Oz Y, Aslan M, Aksit F, Metintas S, Gunduz E. The effect of clinical characteristics on the performance of galactomannan and PCR for the diagnosis of invasive aspergillosis in febrile neutropenic patients. Mycoses 2016;59:86-92.

56. Morton CO, White PL, Barnes RA, Klingspor L, Cuenca-Estrella $M$, Lagrou $K$, et al. Determining the analytical specificity of PCR-based assays for the diagnosis of IA: What is Aspergillus? Med Mycol 2017;55:402-13.

57. Dannaoui E, Gabriel F, Gaboyard M, Lagardere G, Audebert L, Quesne G, et al. Molecular diagnosis of invasive aspergillosis and detection of azole resistance by a newly commercialized PCR kit. J Clin Microbiol 201 7;55:3210-8.

58. Fuchs S, Lass-Florl C, Posch W. Diagnostic performance of a novel multiplex PCR assay for candidemia among ICU patients. J Fungi (Basel) 2019;5(3):86.

59. Baldin C, Soliman SSM, Jeon HH, Alkhazraji S, Gebremariam T, Gu Y, et al. PCR-based approach targeting Mucorales-specific gene family for diagnosis of mucormycosis. I Clin Microbiol 2018;56(10):e00746-18.

60. Springer J, Lackner M, Ensinger C, Risslegger B, Morton CO, Nachbaur D, et al. Clinical evaluation of a Mucorales-specific real-time PCR assay in tissue and serum samples. I Med Microbiol 2016;65:1414-21.

61. Ala-Houhala M, Koukila-Kahkola P, Antikainen J, Valve J, Kirveskari J, Anttila VJ. Clinical use of fungal PCR from deep tissue samples in the diagnosis of invasive fungal diseases: a retrospective observational study. Clin Microbiol Infect 2018;24:301-5.

62. Wehrle-Wieland E, Affolter K, Goldenberger D, Tschudin Sutter S, Halter J, Passweg J, et al. Diagnosis of invasive mold diseases in patients with hematological malignancies using Aspergillus, Mucorales, and panfungal PCR in BAL. Transpl Infect Dis 2018;20:e12953. 
63. Valero C, de la Cruz-Villar L, Zaragoza O, Buitrago MJ. New panfungal real-time $P C R$ assay for diagnosis of invasive fungal infections. J Clin Microbiol 2016;54:2910-8.

64. Massire C, Buelow DR, Zhang SX, Lovari R, Matthews HE, Toleno DM, et al. PCR followed by electrospray ionization mass spectrometry for broad-range identification of fungal pathogens. J Clin Microbiol 2013;51:959-66.?

\section{Yazıșma Adresi/Address for Correspondence}

Doc. Dr. Dolunay GÜLMEZ

Hacettepe Üniversitesi Tip Fakültesi, Tibbi Mikrobiyoloji Anabilim Dalı, Ankara-Türkiye

E-posta: dolunayglm@gmail.com 